\title{
Między teologią a poezją. Przebaczenie u Mickiewicza
}

W roku 1991 w lubelskim Ethosie wydrukowany został szkic Czesława Zgorzelskiego „, Gdy czuwa tylko zgryzota i skrucha...”. Powaga etyczna w postawie twórczej Mickiewicza ${ }^{1}$. Jeden z najwybitniejszych badaczy romantycznego poety dokonuje odsłony i pewnego wyodrębnienia problemu, który dla autora Dziadów był niewątpliwie problemem pierwszym. Jeśli bowiem zobaczymy romantyzm jako czas zmiany pola widzenia - z perspektywy zewnętrznej na wewnętrzną, introspekcyjną - wówczas sprawa sumienia w utworach Mickiewicza odsłoni się jako jeden z najważniejszych - może najważniejszy? - problemów tego pisarstwa. Zgorzelski uruchomił w swoim szkicu „linię domina”, sięgającą szeregu problemów pierwszorzędnych, uwarunkowaną przez sferę przeżyciową, charakterystyczną dla twórczości tego poety. Badacz przywołuje jego słowa: „(...) oprócz win własnych innego prawdziwego nieszczęścia na tym świecie nie ma"2. I kontynuując myśl, cytuje Zgorzelski inny sąd poety: „,...) spowiedź pierwszy krok ku sa-

* Prof. zw. dr hab. Bernadetta Kuczera-Chachulska jest kierownikiem Katedry Badań nad Romantyzmem i Twórczością Cypriana Norwida w Wydziale Nauk Humanistycznych Uniwersytetu Kardynała Stefana Wyszyńskiego w Warszawie. Adres: Wydział Nauk Humanistycznych UKSW, ul. Dewajtis 5, 01-815 Warszawa; e-mail: bernchach@gmail.com.

${ }^{1}$ Czesław Zgorzelski, ,W Tobie jest świattość”. Szkice o liryce religijnej Oświecenia i Romantyzmu (Lublin: Redakcja Wydawnictw KUL, 1993), 71.

2 Tamże, 55-73. 
memu sobie, ku temu źródłu w głębi ducha tryskającemu, skąd oczyściwszy brzegi, wszystko trzeba dobywać"3.

Słowa te wypowiedziane zostały przez Mickiewicza około 1842 roku, zatem już po wydaniu największych dzieł jego życia. Spowiedź, o której mówił poeta, wprowadza w wymiar przebaczenia, przebaczenie zaś dotyczy zarówno relacji międzyludzkich, jak i tego, co wydarza się między człowiekiem a Bogiem. Figura spowiedzi, przyjmująca rozmaite kształty obrazowe, symboliczne, ale zawsze psychologicznie i duchowo realne, daje się odnaleźć w najważniejszych tekstach poety. Są to zarówno największe utwory Mickiewicza - Dziady cz. III i Pan Tadeusz, jak i wiersze, teksty niewielkich rozmiarów, w których spowiedź (jej figura), rozumiana na sposób głęboki i pełny, chociaż nie zawsze wprost, odgrywa znaczącą rolę.

Być może najbardziej znany (i w związku z tym zbanalizowany) jest obraz ze sceny ostatniej rozmowy Jacka Soplicy - Księdza Robaka z Gerwazym w Księdze X Pana Tadeusza („Emigracja. Jacek”). Charakterystyczny dla Mickiewicza poety zwyczaj aktualizacji wydarzeń z różnych momentów czasowych, wydarzeń o zbliżonym lub tożsamym sensie egzystencjalnym (np. wspomnienie we wspomnieniu, umieszczone w jeszcze jednym wspomnieniu $)^{4}$, również w tej księdze Pana Tadeusza został zrealizowany. Jacek Soplica znajdujący się na łożu śmierci, oczekujący na przebaczenie Gerwazego, które ostatecznie się dokona, wysłuchuje w momencie krytycznym, że zamordowany przez niego Stolnik przebaczył mu w chwili śmierci. Poetycki zabieg „,upodwójnienia” przebaczenia decyduje tu o szczególnej intensyfikacji problemu, będącego dla Mickiewicza sprawą pierwszorzędną.

W ogóle w Księdze X dochodzi do tak mocnego zagęszczenia problemów sięgających zarówno najgłębszej przeżyciowej sfery człowieka, jak i przez tradycję usankcjonowanych jako pierwszorzędne, że ze względu na tę częstotliwość i oczywistość istnienia w wyobraźniowej pamięci odbiorcy fabularno-epicki wątek związany z Jackiem Soplicą odbierany zostaje jako „papierowy”, artystycznie mniej udany. Warto zauważyć, że czytelnik przestaje myśleć w ten sposób, kiedy spojrzy na poszczególne wypowiedzi bohaterów w bliskim kontekście wierszy lirycznych Mickiewicza, a zatem tych utworów, w których poeta wypowiada się bardziej bezpośrednio, co do których wiemy również o bliskości osoby mówiącej i instancji autorskiej.

3 Tamże, 71.

${ }^{4}$ Por. sytuację z IV cz. Dziadów. Pisałam na ten temat w szkicu: „O kształcie gatunkowym IV części Dziadów”, w: Bernadetta Kuczera-Chachulska, Przemiany form i postaw elegijnych. Mickiewicz, Stowacki, Norwid, Faliński, Asnyk, Konopnicka (Warszawa: Wydawnictwo Naukowe UKSW, 2002). 
Spójrzmy zatem na tekst, na wybrane fragmenty dotyczące problemu. Mówi Jacek po zarysowaniu się powodów konfliktu, dobrze czytelnikom Pana Tadeusza znanych:

Szatan dumy zaczął mi lepsze plany raić:

Zemścić się krwawo, ale powód zemsty taić,

Nie bywać w zamku, miłość z serca wykorzenić,

Puścić w niepamięć Ewę, z inną się ożenić,

A potem, potem jaką wynaleźć zaczepkę,

Pomścić się 5

Jak informuje jednak edytor tekstu, ostatni wers pierwotnie miał inny kształt:

Tak szatan zawsze radzi, zbrodnią leczyć winę, I ze złej drogi radzi uciekać w głębinę ${ }^{6}$.

Mickiewicz doskonale zdaje sobie sprawę z „zaraźliwej” natury zła; wie, że na zasadzie wpisanego w naturę człowieka automatycznego i ,przymusowego" niemal reagowania na doznaną krzywdę pragnieniem odpłaty pomsty, wchodzi ów człowiek w niekończący się lańcuch zla; krzywd i moralnych przestępstw. Przerwać ten łańcuch może jedynie specyficznie ludzki (w genezie swojej nadludzki, Boski) jedyny w swoim rodzaju ,akt łaski”, którym jest przebaczenie. Akt bardzo trudny, wymagający decyzji, uczestnictwa woli człowieka, która zamknie się na doznane zło, dokładniejdokona transformacji tego zła na rzeczywistość bycia „dla...”, po rezygnacji ze zwierzęcego odruchu wyłącznie obrony własnego ,ja”, rozumianego doraźnie. Akt przebaczenia wymaga również wysiłku intelektu, trudu rozpoznania, umożliwiającego dystans; rozpoznania, które umożliwi ten akt. W Księdze X Pana Tadeusza w usta bohatera włożona zostaje opowieść relacjonująca proces dochodzenia do zabójstwa; jest to głębokie, psychologiczne, ale przede wszystkim ponadpsychologiczne samorozpoznanie i samoocena bohatera, można powiedzieć, posługując się terminologią z innego porządku - rachunek sumienia. W ten sposób poprzedzone wyznanie

5 Adam Mickiewicz, Pan Tadeusz czyli ostatni zajazd na Litwie. Historia szlachecka z roku 1811 i 1812 we dwunastu księgach wierszem, oprac. Stanisław Pigoń (Wrocław: Wydawnictwo Ossolineum, 1980), 483.

6 Tamże. 
winy prowadzi nie tylko do przebaczenia, na które zdobędzie się Gerwazy, ale również niespodzianego ujawnienia przez tego bohatera, że Stolnik już w momencie śmierci przebaczył zabójcy. Zanim jednak dojdzie do kluczowego dla całej sytuacji odsłonięcia dawnego, dokonanego już przebaczenia, czytelnik poematu zostaje wprowadzony w niezwykle dynamiczny proces dojścia do tego uwolnienia od winy. Gerwazy bowiem, śmiertelnie dotknięty zabójstwem Stolnika, noszący je w sobie i pielęgnujący żądzę odwetu przez długi czas, w sposób psychologicznie jakby naturalny nie może zmienić od razu swojej postawy.

Jacek rękę wyciagnął - cofnął się Gerwazy:

„Nie moge - rzekł - bez mego szlachectwa obrazy

Dotykać rękę takim morderstwem skrwawioną

Z prywatnej zemsty, nie zaś pro publico bono".

Ale Jacek, z poduszek na łoże upadłszy,

Zwrócił się ku Sędziemu, a był coraz bladszy

I niespokojnie pytał o księdza plebana,

I wołał na Klucznika: „Zaklinam Waćpana,

Abyś został; wnet skończę, ledwie mam dość mocy

Zakończyć...Panie Klucznik!...ja umrę tej nocy!”

„Co bracie? - krzyknął Sędzia - widziałem, wszak rana

Niewielka, co ty mówisz? po księdza plebana?

Może źle opatrzono - zaraz po doktora,

W apteczce jest..."

Ksiądz przerwał: „Bracie, już nie pora.

Miałem tam strzał dawniejszy, dostałem pod Jena,

Źle zgojony, a teraz drażniono - gangrena

Już tu - znam się na ranach, patrz, jaka krew czarna

Jak sadza; co tu doktor? Ale to rzecz marna;

Raz umieramy, jutro czy dziś oddać duszę...-

Panie Klucznik, przebaczysz mnie, ja skończyć muszę!

Po tych słowach następujący monolog, w którym bohater ,uświadamia sobie" winę przed Gerwazym, jest nie tylko formą samousprawiedliwienia (Jacek bowiem z niezwykłym spokojem i „na zimno" kwalifikuje swój czyn jako zły), ile również przygotowaniem Gerwazego - w trybie rosnącego po- 
ematowego napięcia - do ostatecznego przebaczenia konającemu Jackowi; autor Pana Tadeusza daje Gerwazemu szansę na osiagnięcie duchowej dojrzałości, to znaczy na decyzję przebaczenia Soplicy morderstwa. Mickiewicz o tej scenie najpewniej myślał od początku pisania poematu; tak często przecież we wcześniejszych jego fragmentach przywoływał obraz Gerwazego, który nosi w sobie przekonanie o bezwzględnej konieczności pomsty. Jacek Soplica sumiennie i bez oszczędzania siebie szacuje swoją winę. Trochę tak, jak Mickiewicz napisał w Rozmowie wieczornej:

Sędzio straszliwy! Tyś ognie rozdmuchał

Sumieniu złemu - a tyś mnie wysłuchał ${ }^{7}$.

Mickiewicz dobrze zdaje sobie sprawę, że przebaczenie, każde przebaczenie, musi być związane z autentycznym i dogłębnym zrozumieniem własnej winy. Na fakt ten wskazuje również struktura, przebieg akcji zarówno w całym Mickiewiczowskim poemacie, jak również w jego Księdze X, dla której w dramatycznym napięciu akcji (wzrastaniu tego napięcia) dochodzi do przygotowania chwili kulminacyjnej to znaczy przebaczenia.

Gerwazy przerywa wyznanie Jacka i mówi:

„Oby tylko równie Bóg przebaczyć raczył!

Przerwał Klucznik. - Jeżeli masz przyjąć wijatyk,

Księże Jacku, toć ja nie Luter, nie syzmatyk!

Kto umierającego smuci, wiem, że grzeszy.

Powiem tobie coś, pewnie to ciebie pocieszy:

Kiedy nieboszczyk pan mój upadał zraniony,

A ja, klęcząc nad jego piersią pochylony

I miecz maczając $\mathrm{w}$ ranę, zemstę zaprzysięgnął,

Pan głowę wstrząsnął, rękę ku bramie wyciągnął

W stronę, gdzie stałeś, i krzyż w powietrzu naznaczył;

Mówić nie mógł, lecz dał znak, że zbójcy przebaczył.

Ja też pojąłem, ale tak się z gniewu wściekłem,

Że o tym krzyżu nigdy i słowa nie rzekłem"8.

${ }^{7}$ Adam Mickiewicz, Dzieła, Wydanie Rocznicowe, 1798-1998, t. 1: Wiersze, oprac. Czesław Zgorzelski (Warszawa: Wydawnictwo Czytelnik, 1993), 328.

8 Tamże, 495-496. 
Dla Mickiewicza gest uczynienia krzyża jako znaku przebaczenia jest czymś oczywistym (,,i krzyż w powietrzu naznaczył”). Gest zwyczajny, wydawałoby się w kontekście kultury i tradycji, w obrębie których wypowiada się Mickiewicz jako poeta. Ale gest ten właśnie u Mickiewicza jest gestem ponadkulturowym, zwracającym się w stronę biblijnego kerygmatu, który dla Mickiewicza stanowi aksjologiczne i ponadaksjologiczne centrum. Jego waga i konkretyzm poświadczone zostają bliskością Sakramentu:

Wszyscy uklękli: a wtem ozwał się przed progiem

Dzwonek: znak, że przyjechał pleban z Panem Bogiem

Po długim czasie wędrówek, w sensie fizycznym, ale też duchowym, dopiero po akcie przebaczenia Jacek Soplica „wraca do siebie”. Jak mówi Paul Ricoeur: „Sumienie jest przede wszystkim poświadczeniem, że mogę być mną samym"9. Jak mówi filozof w dalszej części tej samej pracy:

Tym co sumienie potwierdza, jest to, że powinienem w sensie czysto formalnym odróżnić dobro od zła; mogę to zrobić i każdy człowiek jak ja to może [zatem uzyskać stan umożliwiający przebaczenie - B. K.-Ch]. Oto jedno ze znaczeń, jakie można przypisać temu wersetowi z prologu do Ewangelii św. Jana: „Była światłość prawdziwa, która oświeca każdego człowieka”"10.

W takim kontekście jeszcze wyraźniejsze i bardziej zrozumiałe staje się zamknięcie Księgi X:

Właśnie już noc schodziła i przez niebo mleczne,

Różowe, biegą pierwsze promyki słoneczne;

Wpadły przez szyby jako strzały brylantowe,

Odbiły się na łożu o chorego głowę

I ubrały mu złotem oblicze i skronie,

Że błyszczał jako święty w ognistej koronie ${ }^{11}$.

Zatem „punkt krytyczny” przebaczenia staje się ostatecznym przerwaniem zamkniętego łańcucha, który tworzy wina i odwet, staje się również

9 Paul Ricoeur, Miłość i sprawiedliwość, thum. Marek Drwięga (Kraków: Wydawnictwo Universitas, 2010), 142.

10 Tamże, 143.

11 Mickiewicz, Pan Tadeusz, 497-498. 
i w związku z tym rodzajem uwolnienia pojedynczej egzystencji do wejścia na drogę autentycznego wzrostu i przejścia w „krąg światła”, o którym mówił św. Jan Ewangelista, przywołany przez Ricoeura. Dzięki przebaczeniu, a zatem takiej odpowiedzi na zło, które je „ubezwłasnowolnia”, kiedy zło-czyńca to zło uzna i osądzi, możliwa jest dalsza droga, taka, u kresu której nie czyha nicość i pustka.

Księga X Pana Tadeusza stanowi najwyrazistsze w twórczości romantycznego poety liryczne studium przebaczenia. Charakterystyczne dla tego autora bycie ,poetą przemian” warunkowane jest, czasami w ukryty i sublimowany sposób, pracą sumienia i przebaczeniem lub otwarciem się na nie. Dotyczy to zarówno relacji między bohaterami utworów Mickiewicza (w których najczęściej osadza się elementarne autorskie doświadczenie), jak i poetyckich aktów ogarniania całego życia podmiotu i stawiania go wobec Boga. Z tekstów tego poety wypływa również bardzo subtelna świadomość niekończącej się pracy sumienia $\mathrm{i}$ - pośrednio - nieustającej konieczności przebaczenia. Po dłuższym rozpamiętywaniu własnych dawnych przejść stwierdza Soplica: „Może i teraz, kto wie? możem znowu zgrzeszył!”12.

Sumienie bohaterów Mickiewicza jest czujne, zdaje się ustawicznie otwarte na możliwość przebaczenia, które jednak, jeśli się pojawia, jest rezultatem bardzo trudnego - co obrazuje też struktura lirycznej opowieści samorozpoznania, autentycznego żalu i pragnienia wyzwolenia się z uścisku „łańcucha zła”.

Przebaczenie jako rezultat miłosierdzia Bożego pojawi się w kluczowym momencie III cz. Dziadów, które Darring opisze jako dramat zawierający w sobie figurę Sakramentu Pokuty ${ }^{13}$. W kluczowym dla tej refleksji, ale i dla dramatu momencie odnajdujemy taki dialog:

Ks. Piotr

Módl się, bo strasznie Pańska dotknęła cię ręka.

Usta, którymiś wieczny Majestat obraził,

Te usta zły duch słowy szkaradnymi skaził;

Słowa głupstwa, najsroższa dla mądrych ust męka,

Oby ci policzone były za pokutę,

Obyś o nich zapomniał -

12 Tamże, 494.

13 Gerald Darring, „Jedność strukturalna «Dziadów» cz. III”, w: Dramat i teatr religijny w Polsce, red. Irena Sławińska, Wojciech Kaczmarek, wstęp: J. Lewański (Lublin: Towarzystwo Naukowe KUL, 1991). 
Konrad

Już są tam - wykute.

Ks. Piotr

Obyś, grzeszniku, nigdy sam ich nie wyczytał,

Oby cię o znaczenie ich Bóg nie zapytał -

Módl się; myśl twoja w brudne obleczona słowa,

Jak grzeszna $\mathrm{z}$ tronu swego strącona królowa,

Gdy w żebraczej odzieży, okryta popiołem,

Odstoi czas pokuty swojej przed kościołem,

Znowu na tron powróci, strój królewski wdzieje

I większym niźli pierwej blaskiem zajaśnieje.

Usną -

(klęka)

- Twe miłosierdzie, Panie, jest bez granic.

(pada krzyżem)

Panie, otom ja sługa dawny, grzesznik stary,

Sługa już spracowany niezgodny na nic.

Ten młody, zrób go za mnie sługą Twojej wiary,

A ja za winy przyjmę wszystkie jego kary.

On poprawi się jeszcze, on wsławi Twe imię.

Módlmy się, Pan nasz dobry! Pan ofiarę przyjmie.

Scena z III cz. Dziadów jest bezwzględnym warunkiem dalszej drogi Konrada, drogi ku niedopowiedzianemu w dramacie spełnieniu, drogi człowieka, który odzyskał swoją wewnętrzną moralną i duchową pełnię i który będzie mógł podjąć się w przyszłości zadań, które wcześniej przekreślił występek pychy.

Kwestia winy, samorozpoznania i wybaczenia wpisana jest u Mickiewicza w porządek bardzo konkretny: historyczny, psychologiczny i duchowy. Wszystkie te porządki obdarzone zostały przez poetę oczywistością realizmu. Strefa psychologii staje się furtką do rzeczywistości ducha, uogólnionej ostatecznie w przestrzeni znaczeń metafizycznych i teologicznych jednocześnie.

Wydaje się, że to literatura romantyczna przygotowała wielkie sceny w polskiej powieści pozytywistycznej np. przebaczenie Juranda oprawcy córki Danusi w Krzyżakach Sienkiewicza czy może mało ostre, ale jednak obecne, „uprzedzające” jakby przebaczenie w wierszu Konopnickiej Pocatunek Roberta Emmeta: 
I pochylił swą tragiczną głowę:

- Przez te rany... przez te Chrystusowe...

I ostatnim pocałunkiem brata

Ucałował straszne lico kata ${ }^{14}$.

\section{Between Theology and Poetry: Forgiveness in the Works of Mickiewicz \\ (Summary)}

The article begins with the reflection of $\mathrm{Cz}$. Zgorzelski on the religious issues in the works of Mickiewicz, which have been dominated with question of conscience. The most important works of the poet and their principal threads are strictly connected to the inner transformation and maturation of the characters. Pan Tadeusz, Dziady part III as well as the lyrical works of Mickiewicz include these problems. The issue of the guilt, self-discovery and forgiveness is most broadly and elaborately depicted in Pan Tadeusz (Volume X „Emigracja. Jacek”). This nearly exemplary situation of inner state of the character that is striving for deliverance from nagging guilt has been analyzed in context of the thoughts of P. Riceur. The act of forgiveness shown by the most important of Polish romantic poets, preceded the big scenes concerning this problem in the following Polish literature.

Key words: conscience; self-discovering; penitence; Mickiewicz; Ricoeur; forgiveness; deliverance; spiritual maturity.

\section{Między teologią a poezją. Przebaczenie u Mickiewicza (Streszczenie)}

Szkic otwiera przywołanie refleksji Cz. Zgorzelskiego na temat problematyki religijnej w twórczości Mickiewicza, która zdominowana została przez kwestie sumienia. Najważniejsze utwory poety, ich zasadnicze wątki, połączone są ściśle z duchową drogą przemiany i wewnętrznego dojrzewania bohaterów. Taki motyw odnajdujemy zarówno w Panu Tadeuszu, jak i w Dziadów cz. III, a także liryce Mickiewicza. Najszerzej i najbardziej wyraźnie przedstawiony został problem winy, samorozpoznania i przebaczenia w Panu Tadeuszu (księga X: „Emigracja. Jacek”). Ta

${ }^{14}$ Cyt. za: Od Kochanowskiego do Staffa. Antologia liryki polskiej, ułożył Wacław Borowy (Warszawa: PIW, 1958), 240. 
modelowa niemal sytuacja stanu wewnętrznego bohatera, dążącego do uwolnienia od dręczącej go winy, przeanalizowana została z uwzględnieniem kontekstu refleksji P. Ricoeura. Akt wybaczenia, przedstawiony przez największego polskiego romantyka, poprzedził wielkie sceny, dotyczące tego właśnie problemu w późniejszej literaturze polskiej.

Slowa kluczowe: sumienie; skrucha; samopoznanie; Mickiewicz; Ricoeur; wybaczenie; uwolnienie; duchowa dojrzałość.

\section{Bibliografia}

Darring, Gerald. „Jedność strukturalna «Dziadów» cz. III”. W: Dramat i teatr religijny w Polsce, red. Irena Sławińska, Wojciech Kaczmarek, wstęp: J. Lewański. Lublin: Towarzystwo Naukowe KUL, 1991.

Kuczera-Chachulska, Bernadetta. Przemiany form i postaw elegijnych. Mickiewicz, Stowacki, Norwid, Faliński, Asnyk, Konopnicka. Warszawa: Wydawnictwo Naukowe UKSW, 2002.

Mickiewicz, Adam. Dzieła, Wydanie Rocznicowe, 1798-1998, t. I: Wiersze, oprac. Czesław Zgorzelski. Warszawa: Wydawnictwo Czytelnik, 1993.

Mickiewicz, Adam. Pan Tadeusz czyli ostatni zajazd na Litwie. Historia szlachecka z roku 1811 i 1812 we dwunastu ksieggach wierszem, oprac. Stanisław Pigoń. Wrocław: Wydawnictwo Ossolineum, 1980.

Od Kochanowskiego do Staffa. Antologia liryki polskiej, ułożył Wacław Borowy. Warszawa: PIW, 1958.

Ricoeur, Paul. Miłość i sprawiedliwość, thum. Marek Drwiegga. Kraków: Wydawnictwo Universitas, 2010.

Zgorzelski, Czesław. , W Tobie jest świattość”. Szkice o liryce religijnej Oświecenia i Romantyzmu. Lublin: Redakcja Wydawnictw KUL, 1993. 